\title{
基于杯芳烃和紫精的电刺激响应二元水凝胶
}

\author{
王振郭东升张捷刘育* \\ (南开大学化学学院 元素有机化学国家重点实验室 天津 300071)
}

\begin{abstract}
摘要 基于上缘四脯氨酸修饰杯 [4]芳烃和各种紫精客体分子的相互作用, 我们构筑了一类新型的二元超分子水凝胶. 得到结果显示, 在酸性条件下, 溴化紫精盐最易于促进四脯氨酸修饰杯 [4]芳烃形成水凝胶. 并且经落球法测定了所制 备水凝胶的凝胶一溶胶转变温度, 采用原子力显微镜和扫描电子显微镜表征了水凝胶的微观形态, 发现紫精的侧链对 水凝胶性质具有显著影响, 包括凝胶一溶胶转变温度和微观形态. 值得注意的是, 该类水凝胶不仅具有优良的电刺激响 应性，而且能够通过化学、 $\mathrm{pH}$ 和热等多种因素进行调控.
\end{abstract}

关键词 小分子水凝胶; 杯芳烃; 紫精; 电响应

\section{Electro-responsive Binary Hydrogels Based on Calixarene and Viologens}

\author{
Wang, Zhen Guo, Dongsheng Zhang, Jie Liu, Yu* \\ (Department of Chemistry, State Key Laboratory of Elemento-Organic Chemistry, Nankai University, Tianjin 300071, China)
}

\begin{abstract}
We built several supramolecular binary hydrogels based on tetra-proline modified calix[4]arene (TPC) and various viologens. The obtained results show that the TPC gelation is mostly achieved with viologen bromides in acidic condition. The variation of viologen side-chains has notable impact on the properties of the hydrogels, such as the gel-sol transition temperature $\left(T_{\mathrm{gel}}\right)$ and morphology, which were evaluated by the combination of dropping-ball method, atomic force microscopy and scanning electron microscopy. The prepared hydrogels are significantly electro-responsive, as well as chemical-sensitive, $\mathrm{pH}$-sensitive and thermo-reversible.

Keywords low molecular weight hydrogel; calixarene; viologen; electro-response
\end{abstract}

\section{Introduction}

Low molecular weight gels (LMWGs), which arise from the self-assembly of low molecular weight compounds, ${ }^{[1]}$ have received considerable attention because of their various potential applications in sensors, electrooptics/ photonics, structure directing agents, cosmetics, conservation of arts, drug delivery and bio-medical applications etc. ${ }^{[2]}$ As comparison with common polymer gels, many of the LMWGs are more easily to degrade since they are derived from biocompatible components and are held together by noncovalent forces. ${ }^{[2]}$ To achieving the advantage, several efforts have been devoted to generate external stimuli-responsive gels by grafting LMWGs with photoresponsive/electroactive/chemically reactive group. ${ }^{[3-6,8]}$ As a representative example, Zhu and coworkers reported a LMWG with the electro-responsive tetrathiafulvalene and photo-responsive azobenzene groups. The resulting organogels respond to both redox reactions and light irradiation. ${ }^{[/]}$

In the other way, from a modern scientific perspective, water supports most living organisms on our planet by mediating and regulating complex biological processes. ${ }^{[8]}$ The gels of aqueous solutions (hydrogels) are widely used in personal care products and foods and their potential for new biomedical applications. ${ }^{[9]}$ As a result, current interest in low molecular weight hydrogels (LMWHs) is growing rapidly. Not all noncovalent interactions are always effective in aqueous medium, and thereby, the water-soluble macrocyclic receptors, such as cyclodextrins, calixarenes, and cucurbiturils, emerge to be an alternative way to form LMWHs. ${ }^{[10]}$ Osakada and co-workers found that pseudorotaxanes composed of an alkylpyridinium and $\alpha$-cyclodextrin $(\alpha-\mathrm{CD})$ presents a facile binary component LMWH, which show sol-gel transitions at $7-67{ }^{\circ} \mathrm{C}$ depending on the type and amount of the guest compound. ${ }^{[1]}$ Kim and co-workers reported that cucurbit[7]uril forms a hydrogel without modification of its periphery, the gelation is thermoreversible, sensitive to $\mathrm{pH}$, and inhibited by the presence of alkali-metal ions. Furthermore, the cucurbit[7]uril hydrogel shows a guest-induced stimuli-responsive sol-gel transition. ${ }^{[12]}$ Recently, Mocerino and coworkers reported the first calixarene-based hydrogelator, a tetraproline-functionalised calix[4]arene (TPC), which has been found to form hydrogels when triggered by the presence of specific anions. ${ }^{[13]}$ Further study on the solution-phase and solid-state structures of TPC show that the remarkable hydrogelation properties of a TPC emerge as a result of extended helical structures formed via inclusion

*E-mail: yuliu@nankai.edu.cn; Tel.: 0086-022-23503625; Fax: 0086-022-23503625.

Received June 1, 2012; published July 2, 2012.

Supporting information for this article is available free of charge via the Internet at http://sioc-journal.cn

Project supported by 973 Program (2011CB932502) and the National Natural Science Foundation of China (Nos. 20932004, 21172119).

项目受 973 计划(2011CB932502)和国家自然科学基金(Nos. 20932004, 21172119)资助. 
of a proline moiety in a neighbouring calixarene cavity. ${ }^{[14]}$ More recently, our group also found that basic amino acids can trigger TPC forming binary hydrogels efficiently, and moreover, can modulate the LMWH morphologies. ${ }^{[15]}$ In this proceeding work, we further built several LMWHs based on TPC gelator and various viologen salts (Scheme 1). Viologens are one class of important redox couples, ${ }^{[16]}$ widely utilized as subunits in constructing functional molecular assemblies/machines and as components of electrochromic display devices. ${ }^{[17,18]}$ Employing viologens herein is to endow the supramolecular binary hydrogels desired electro-responsive capability. ${ }^{[19]}$ Up to now, although a great variety of examples of LMWHs have been reported, it is almost neglected that fabrication of LMWHs with electro-response. Redox-responsive systems may be applied to environmentally benign electro-functional systems, such as electrically switchable materials. ${ }^{[20]}$ Thus, we are motivated to construct electro-responsive hydrogel systems.

\section{Results and discussion}

\subsection{Formation of hydrogels}

Several viologen salts with different counter-ions and side-chains were used to examine the gelation behavior of TPC (Table 1). The TPC gelation is primarily dependent on the anions added to the solution according to previous report. ${ }^{[13]}$ We firstly explored the TPC gelation upon addition of various viologen salts with different counter-anions $\left(\mathrm{Cl}^{-}, \mathrm{Br}^{-}, \mathrm{I}^{-}, \mathrm{NO}_{3}^{-}\right)$. In case of chloride, the gelation was failed and the mixture remained as a solution when $1: 1$ mixing TPC and viologen chlorides with concentration at $5.0 \mathrm{mmol} / \mathrm{L}$. It should be noticed that the hydrogels can be formed when the concentration of TPC increases to 10.0 $\mathrm{mmol} / \mathrm{L}$ with 4 equiv. viologen chlorides. The hydrogels can be formed with a good stability when $1: 1$ mixing TPC and viologen bromides with concentration at 5.0 $\mathrm{mmol} / \mathrm{L}$. The obtained LMWHs are not destroyed even after standing for one week. The viologen nitrate can induce the TPC gelation at the beginning of adjusting $\mathrm{pH}$
3.0 , but the hydrogel subsequently transformed to a microcrystalline needle-like precipitate in $2 \mathrm{~h}$. In the case of iodide, a cotton-like precipitate was obtained when adding 1 equiv. viologen iodide to $5.0 \mathrm{mmol} / \mathrm{L}$ TPC solution. Several attempts to gelation with different concentrations and mixing ratios were all failed. As can be seen from the above results, The TPC gelation is mostly achieved with viologen bromides. The effect of anions to TPC gelation has been demonstrated by Ogden and coworkers that anions also play crucial role in determining how these host guest pairs aggregate to form ultimately networks that stabilizes gels. ${ }^{[14]}$ Several kinds of viologen bromides with different side-chains can all lead to the TPC gelation satisfiedly, however, the variation of viologen side-chains has notable impact on the properties of the hydrogels, such as the gel-sol transition temperature $\left(T_{\mathrm{gel}}\right)$ and morphologies, which will be discussed detailedly in the aftermentioned section.

Taking the $\mathrm{TPC} / \mathrm{MV}^{2+} \cdot 2 \mathrm{Br}^{-}$hydrogel as a representative example, we optimized the gelation condition from the viewpoints of the ratio of $\mathrm{TPC} / \mathrm{MV}^{2+} \cdot 2 \mathrm{Br}^{-}$ranging from $1 / 4$ to $4 / 1$ ( $\mathrm{mol} / \mathrm{mol})$, TPC concentrations from $1.0 \mathrm{mmol} / \mathrm{L}$ to $20.0 \mathrm{mmol} / \mathrm{L}$, and $\mathrm{pH}$ varied from 7.0 to 1.0 . We found that $5.0 \mathrm{mmol} / \mathrm{L}$ of TPC with 1 equiv. $\mathrm{MV}^{2+} \cdot 2 \mathrm{Br}^{-}$yields stable transparent hydrogel when $\mathrm{pH}$ decreased to 3.0 (Figure 1a). The hydrogel can not be formed when the concentration of TPC is below $5.0 \mathrm{mmol} / \mathrm{L}$. The hydrogels turn to be opaque with the TPC concentration higher than $15.0 \mathrm{mmol} / \mathrm{L}$. The same optimal condition was also obtained for other viologen bromides. The gelation mechanism of TPC with viologen bromides was hypothesized as followed: TPC forms nanoscaled particles with negative charges in free TPC solution when concentration over its CMC (critical micelle concentration), ${ }^{[13]}$ and then viologen bromides interact with the TPC micelles through non-covalent interactions (electrostatic, host-guest and van der Waals interactions are considered to be involved in) to joint them together, leading to the formation of hydrogels (Scheme 2).

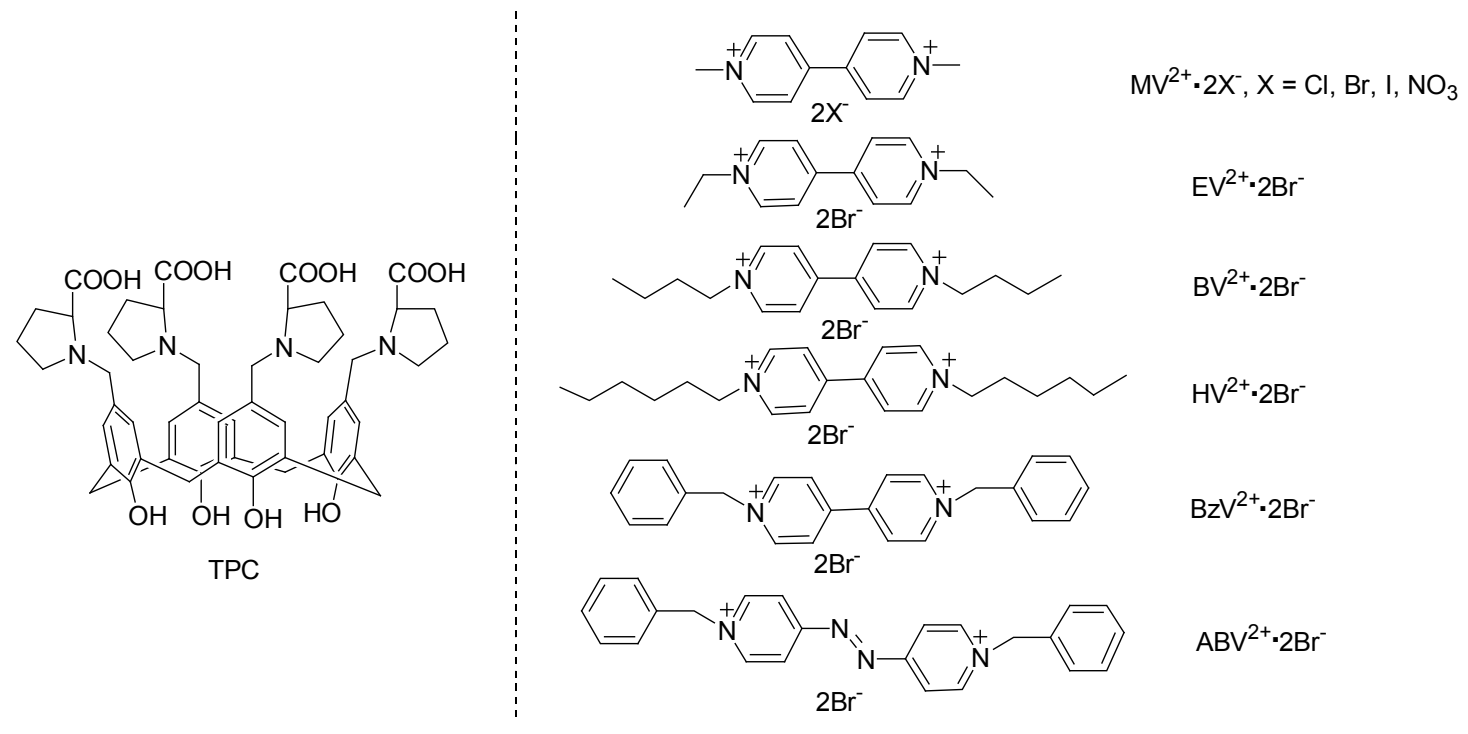

Scheme 1 Structural illustration of TPC and viologens salts 
Table 1 Gelation performances of TPC with viologen salts ${ }^{a}$

\begin{tabular}{lll}
\hline & $\mathrm{pH} 7.0$ & $\mathrm{pH} 3.0$ \\
\hline $\mathrm{MV}^{2+} \cdot 2 \mathrm{Br}^{-}$ & $\mathrm{S}$ & $\mathrm{G}$ \\
$\mathrm{EV}^{2+} \cdot 2 \mathrm{Br}^{-}$ & $\mathrm{S}$ & $\mathrm{G}$ \\
$\mathrm{BV}^{2+} \cdot 2 \mathrm{Br}^{-}$ & $\mathrm{S}$ & $\mathrm{G}$ \\
$\mathrm{HV}^{2+} \cdot 2 \mathrm{Br}^{-}$ & $\mathrm{S}$ & $\mathrm{G}$ \\
$\mathrm{OV}^{2+} \cdot 2 \mathrm{Br}^{-}$ & $\mathrm{S}$ & $\mathrm{G}$ \\
$\mathrm{BzV}^{2+} \cdot 2 \mathrm{Br}^{-}$ & $\mathrm{S}$ & $\mathrm{G}$ \\
$\mathrm{ABV}^{2+} \cdot 2 \mathrm{Br}^{-}$ & $\mathrm{S}$ & $\mathrm{G}$ \\
$\mathrm{MV}^{2+} \cdot 2 \mathrm{Cl}^{-}$ & $\mathrm{S}$ & $\mathrm{S}$ \\
$\mathrm{BzV}^{2+} \cdot 2 \mathrm{Cl}^{-}$ & $\mathrm{S}$ & $\mathrm{S}$ \\
$\mathrm{MV}^{2+} \cdot 2 \mathrm{NO}_{3}^{-}$ & $\mathrm{S}$ & $\mathrm{C}$ \\
$\mathrm{MV}^{2+} \cdot 2 \mathrm{I}^{-}$ & $\mathrm{S}$ & $\mathrm{P}$ \\
\hline
\end{tabular}

The concentrations of TPC and viologen salts are $5.0 \mathrm{mmol} / \mathrm{L}$, respectively. ${ }^{a} \mathrm{G}$ $=\mathrm{Gel} ; \mathrm{S}=$ Solution; $\mathrm{P}=$ Precipitate $\mathrm{C}=$ Crystallization

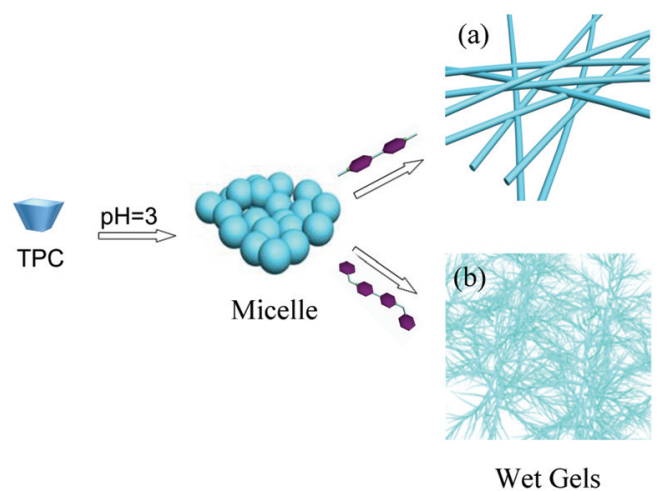

Scheme 2 Schematic illustration of gelation of TPC induced by (a) $\mathrm{MV}^{2+} \cdot 2 \mathrm{Br}^{-}$and (b) $\mathrm{BzV}^{2+} \cdot 2 \mathrm{Br}$

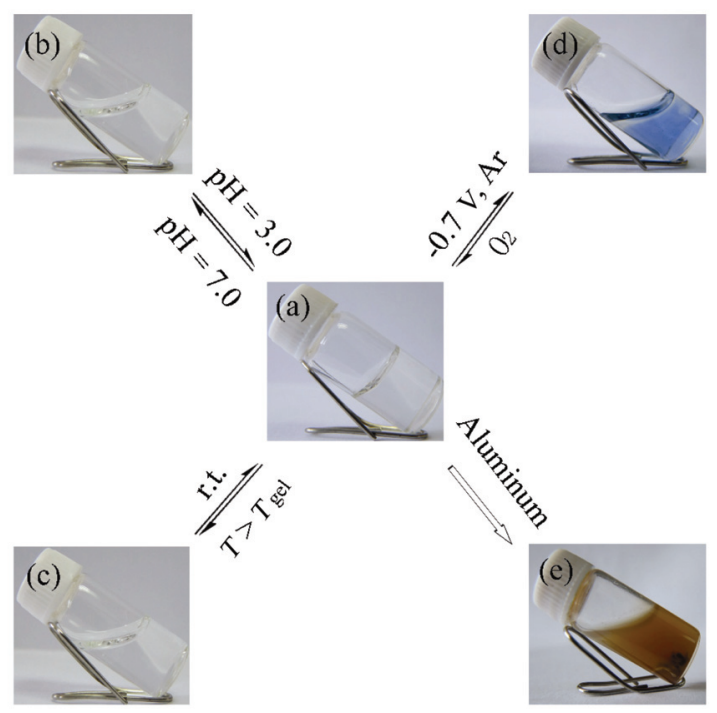

Figure 1 Supramolecular LMWH obtained from TPC with $\mathrm{MV}^{2+} \cdot 2 \mathrm{Br}^{-}$ (a) and its stimuli-responsive property: (b) $\mathrm{pH}$-sensitive gel-sol transition, (c) thermoreversible gel-sol transition, (d) reduction with electro-chemistry, (e) reduction with aluminium sheet

\subsection{Morphological studies of hydrogels}

AFM are high-resolution techniques that have the potential to image hydrated samples in situ under high humidity conditions and without dehydration. ${ }^{[2]}$ Herein, AFM was performed to study the morphological features of the wet hydrogels. With different side-chains, the supramolecular interactions between viologens and TPC might be correspondingly distinguishable. Hence, it is reasonably acceptable that the hydrogels of TPC with different viologen bromides display different morphologies of networks. The obtained AFM images are shown in Figure 2. The $\mathrm{TPC} / \mathrm{MV}^{2+} \cdot 2 \mathrm{Br}^{-}$and $\mathrm{TPC} / \mathrm{HV}^{2+} \cdot 2 \mathrm{Br}^{-}$hydrogels, where viologens possess the alkyl side-chains, are composed of long rodlike nanofibers (Figure $2 \mathrm{a}-2 \mathrm{~d}$ ). Figure $2 \mathrm{e}-2 \mathrm{~h}$ show the denser networks in $\mathrm{TPC} / \mathrm{BzV}^{2+} \cdot 2 \mathrm{Br}^{-}$and $\mathrm{TPC} / \mathrm{ABV}^{2+} \cdot 2 \mathrm{Br}^{-}$hydrogels, where viologens possess the benzyl side-chains. The $\mathrm{TPC} / \mathrm{BzV}^{2+} \cdot 2 \mathrm{Br}^{-}$hydrogel is composed of nanofibers with the lengths of $2.0-5.0 \mu \mathrm{m}$, while the $\mathrm{TPC} / \mathrm{ABV}^{2+} \cdot 2 \mathrm{Br}^{-}$hydrogel is composed of longer and branched fibers. The morphologies of xerogels of TPC/viologen bromides are also different as can be seen from the scanning electron microscopy (SEM) images (Figure S4, Supporting information). Distinguishable microstructures are observed in TPC/viologen bromides hydrogels, indicating that viologens with side-chain variations indeed induce significant morphological changes in binary hydrogels.

\subsection{XRD Patterns}

The molecular length of TPC is $8.5 \AA$, and the distance of the bilayer packing is about $16.0 \AA$ (Figure S1, Supporting information), according to our previous result of crystal structure of TPC formed from the $0.01 \mathrm{~mol} / \mathrm{L} \mathrm{HCl}$ solution. ${ }^{[15]}$ In the XRD pattern of TPC crystal, we observed the peak of $2 \theta=5.4^{\circ}$ (basal spacing $16.8 \AA$ ), which may correspond to the distance of the bilayer structure. Similar peak was also found in the XRD pattern of the $\mathrm{TPC} / \mathrm{HV}^{2+} \cdot 2 \mathrm{Br}^{-}$xerogel (Figure 3 ). It is speculated that there is the similar bilayer molecular packing of TPC in the $\mathrm{TPC} / \mathrm{HV}^{2+} \cdot 2 \mathrm{Br}^{-}$hydrogel, with the proline residues facing the polar solvent and the hydrophobic segment facing inside.

\subsection{Electro-response of the hydrogels}

Viologens are electro-active couples, and therefore, the present binary TPC/viologens hydrogels are assumed to be electro-responsive. As a necessary prerequisite, we measured the electrochemical behaviour of $\mathrm{MV}^{2+} \cdot 2 \mathrm{Br}^{-}$in the presence of TPC by cyclic voltammetry (CV). The obtained CV curves were shown in Figure S5 (Supporting information). Two reduction potentials at $-0.7 \mathrm{~V}$ and $-1.2 \mathrm{~V}$ correspond to the $\mathrm{MV}^{2+} / \mathrm{MV}^{+}$and $\mathrm{MV}^{2+} / \mathrm{MV}$ transformations, respectively. When using the reduction potential $-0.7 \mathrm{~V}$ under the protection of nitrogen, the hydrogel changed to blue solution/sol, indicating that the $\mathrm{MV}^{2+}$ was reduced into $\mathrm{MV}^{+\bullet}$ (Figure 1d). The blue solution/sol turned into colourless after exposed to the air for several seconds, meaning that the $\mathrm{MV}^{+\bullet}$ was reoxidized to $\mathrm{MV}^{2+}$ by oxygen in air. Heating the colourless solution for several minutes and then cooling to room temperature, the gel phase was regenerated. The hydrogel was destroyed after application of a reduction potential $-1.2 \mathrm{~V}$, reducing 

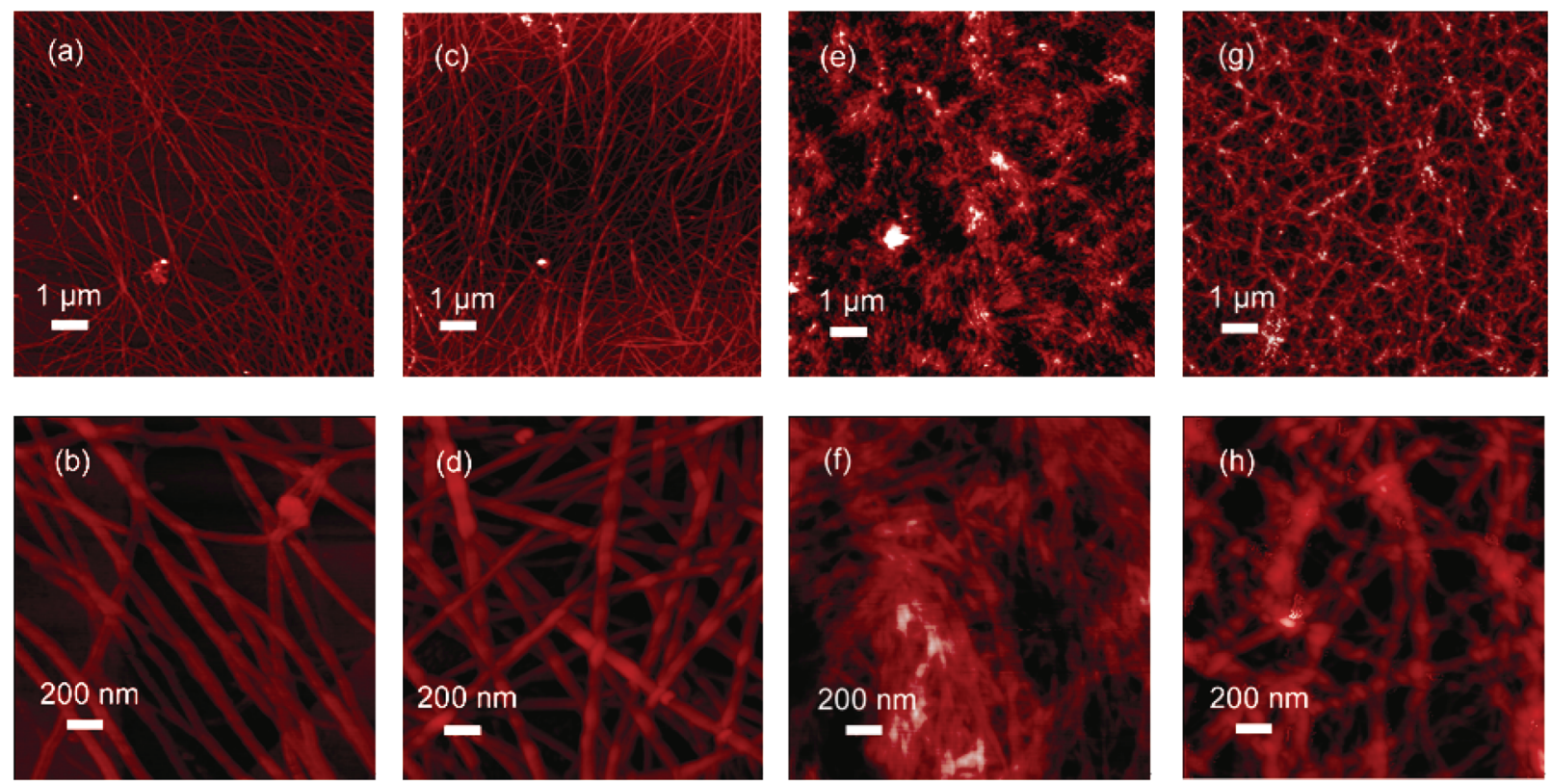

Figure 2 AFM images of wet hydrogels: (a) and (b) $\mathrm{TPC} / \mathrm{MV}^{2+} \cdot 2 \mathrm{Br}^{-}$, (c) and (d) $\mathrm{TPC} / \mathrm{HV}^{2+} \cdot 2 \mathrm{Br}^{-}$, (e) and (f) $\mathrm{TPC} / \mathrm{BzV}^{2+} \cdot 2 \mathrm{Br}^{-}$, (g) and (h) $\mathrm{TPC}^{-\mathrm{ABV}^{2+}}$ • $2 \mathrm{Br}$

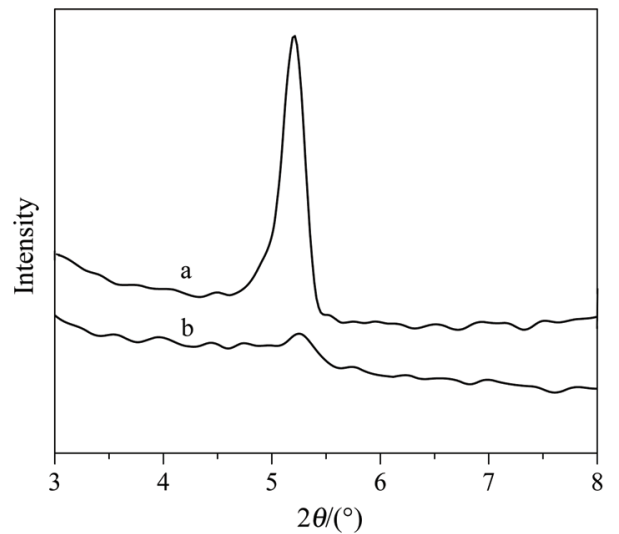

Figure 3 Powder X-ray diffraction patterns for (a) the TPC singlecrystal and (b) the $\mathrm{TPC} / \mathrm{HV}^{2+} \cdot 2 \mathrm{Br}^{-}$xerogel

$\mathrm{MV}^{2+}$ to neutral MV. However, neutral MV was participated from the aqueous solution, which made it difficult to be reoxidized in practical operation. The hydrogel was hard to be regenerated. According to our assumption of hydrogelation mechanism, $\mathrm{MV}^{2+}$ induces the transformation from the TPC micelles into fibers, which is the key factor of hydrogelation. When the $\mathrm{MV}^{2+}$ was reduced, the driving force diminished or even lost, and then, the hydrogel was destroyed. As a control experiment, we investigated the electro-responsibility of hydrogel formed from TPC and $\mathrm{NaBr}$, there was no obvious change occurred. Therefore, electro-responsive hydrogel can be obtained with $\mathrm{TPC} / \mathrm{MV}^{2+} \cdot 2 \mathrm{Br}^{-}$hydrogel.

\subsection{Chemical response of the hydrogels}

It has been reported that chemical reduction of viologens by aluminum foil in dilute aqueous hydrofluoric acid solution. ${ }^{[21]}$ Therefore, we chose the aluminum foil to investigate the chemical-sensitivity of the $\mathrm{TPC} / \mathrm{MV}^{2+} \cdot 2 \mathrm{Br}^{-}$hydrogel. Excess aluminum foil was placed on the top of the hydrogel carefully and blue solution was obtained nearby, indicating $\mathrm{MV}^{2+}$ was reduced into $\mathrm{MV}^{+\bullet}$. The aluminum foil slid into the hydrogel and precipitates were yielded, which meant neutral MV was generated. After several hours standing, the hydrogel was destroyed (Figure 1e). We also found that there was no obvious change of the $\mathrm{pH}$ value. For the neutral MV was participated from the aqueous solution, which made it difficult to be reoxidized in practical operation, the hydrogel can not be regenerated.

\section{6 pH-response of hydrogels}

We have reported before that the TPC/amino acids hydrogels are $\mathrm{pH}$-sensitive. ${ }^{[15]}$ Herein, we investigated the hydrogelation of TPC triggered by viologen bromides with $\mathrm{pH}$ varied from 7.0 to 3.0. The hydrogels can be formed when $1: 1$ mixing $5.0 \mathrm{mmol} / \mathrm{L} \mathrm{TPC}$ and viologen bromides at $\mathrm{pH}$ 3.0. However, the mixture maintained as a solution at $\mathrm{pH} 7.0$ at the same concentration. When $\mathrm{pH}$ was adjusted to 3.0, the solution would change to hydrogel, in contrast, the hydrogel would turn into solution when the $\mathrm{pH}$ value was adjusted to 7.0 (Figure $1 \mathrm{~b}$ ). TPC is one kind of amphiphile that can form micellar aggregation with a $\mathrm{CMC}$ of $5.6 \mathrm{mmol} / \mathrm{L}$ at neutral condition. However, when the $\mathrm{pH}$ value was decreased to 3.0 , the CMC dropped to $1.2 \mathrm{mmol} / \mathrm{L} .{ }^{[13]}$ Furthermore, at $\mathrm{pH} 3.0$, the TPC concentration employed in gelation $(5.0 \mathrm{mmol} / \mathrm{L})$ is over 4 times higher than its CMC. Therefore, the gel-sol-gel transition would occur by adjusting the $\mathrm{pH}$ values.

\subsection{Thermal response of hydrogels}

In order to investigate the thermo-reversibility of TPC/viologen bromides hydrogels, we performed fluorescence spectroscopic studies using 8-anilino-1-naphthalenesulfonic acid sodium salt (ANS) as probe, which is sensitive to a hydrophobic environment. ${ }^{[22]} \mathrm{TPC} / \mathrm{MV}^{2+} \cdot 2 \mathrm{Br}^{-}$, $\mathrm{TPC} / \mathrm{HV}^{2+} \cdot 2 \mathrm{Br}^{-}$and $\mathrm{TPC} / \mathrm{BzV}^{2+} \cdot 2 \mathrm{Br}^{-}$hydrogels were taken as representative examples. The emission intensity of hydrogel-loaded ANS was measured in the temperature 

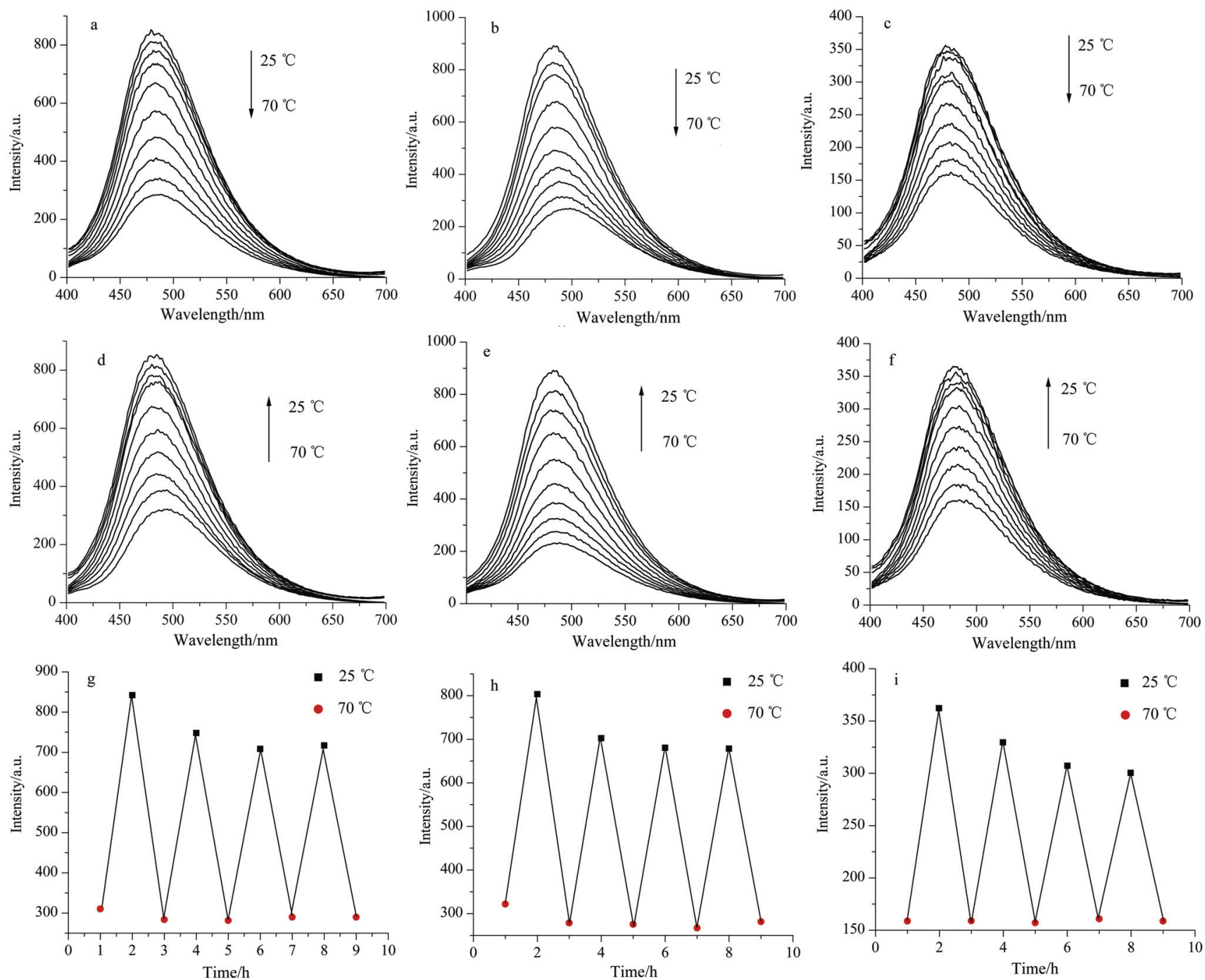

Figure 4 Changes in fluorescence intensity of ANS owing to sequential variations in temperature in (a) and (d) $\mathrm{TPC} \mathrm{MV}^{2+} \cdot 2 \mathrm{Br}^{-}$hydrogel, (b) and (e) $\mathrm{TPC} / \mathrm{HV}^{2+} \cdot 2 \mathrm{Br}^{-}$hydrogel, (c) and (f) $\mathrm{TPC} / \mathrm{BzV}^{2+} \cdot 2 \mathrm{Br}^{-}$hydrogel. Changes in fluorescence intensity of ANS as a function of cyclical variation of temperature between 25 and $70{ }^{\circ} \mathrm{C}$ in (g) TPC/MV ${ }^{2+} \cdot 2 \mathrm{Br}^{-}$, (h) $\mathrm{TPC} / \mathrm{HV}^{2+} \cdot 2 \mathrm{Br}^{-}$and (i) $\mathrm{TPC} / \mathrm{BzV}^{2+} \cdot 2 \mathrm{Br}^{-}$hydrogels. Condition: [TPC] $=[\mathrm{viologen}$ bromides $]=10.0 \mathrm{mmol} / \mathrm{L}$ in water, $[\mathrm{ANS}]=10.0 \mu \mathrm{mol} / \mathrm{L}, \lambda_{\mathrm{ex}}=360 \mathrm{~nm}$

range of $25-70{ }^{\circ} \mathrm{C}$. The fluorescence decreases gradually with elevating temperature (Figure $4 \mathrm{a}-4 \mathrm{f}$ ), which indicates that ANS is exposed to more hydrophilic environment as the gel phase turns to the solution/sol phase. In case of the cooling cycle, the emission intensity increases when temperature decreased from 70 to $25^{\circ} \mathrm{C}$. Furthermore, we investigated the changes in fluorescence intensity of ANS as a function of cyclical variation of temperature between 25 and $70{ }^{\circ} \mathrm{C}$. The results are shown in Figure $4 \mathrm{~g}-4 \mathrm{i}$ that all the temperature-dependent changes are reversible and can be observed for several cycles. These results indicate the thermo-reversible hydrogelation process of TPC/viologen bromides in water. Additionally, we found that the fluorescence of ANS in TPC/BzV $\mathrm{B}^{2+} \cdot 2 \mathrm{Br}^{-}$ hydrogel is obviously lower than those in TPC/MV ${ }^{2+} \cdot 2 \mathrm{Br}$ and $\mathrm{TPC} / \mathrm{HV}^{2+} \cdot 2 \mathrm{Br}^{-}$hydrogel. It should be owing to the different hydrophobic environments provided by hydrogels, which corresponds to the different microstructures and morphologies of hydrogels mentioned above.

\section{Conclusion}

We have successfully constructed a series of LMWHs from TPC gelator triggered by viologens. The TPC gelation is mostly achieved with viologen bromides among various viologen salts used. Viologen bromides with different side-chains can all induce the TPC gelation effectively, but side-chains has notable impact on the properties of the hydrogels, such as $T_{\text {gel }}$ and morphology. More significantly, the obtained hydrogels are multi-responsive to several factors, including chemical, $\mathrm{pH}$, thermal, and especially electro-stimuli. The present study paves an alternative way to build sophisticated stimuli-responsive materials via the bottom-up supramolecular strategy.

\section{Experimental}

\subsection{Materials}

Methyl iodide, 1-bromoethane, 1-bromobutane, 1-bromohexane, benzyl bromide, pyridin-4-amine, 4,4'-bipyridine 
were purchased from Aladdin Chemicals. ANS was obtained from TCI. All the chemicals were used without further purification. Deionized water was used in this work to minimize the interference of metal ions. TPC and viologen salts were synthesized and purified according to the reported procedure.

Synthesis of TPC: Calix[4]arene (1.0 g, $2.4 \mathrm{mmol})$, tetrahydrofuran $(20 \mathrm{~mL})$, proline $(1.5 \mathrm{~g}, 13.0 \mathrm{mmol})$ dissolved in water $(4.0 \mathrm{~mL})$, glacial acetic acid $(3.0 \mathrm{~mL})$ and formaldehyde $(1.1 \mathrm{~mL}, 37 \% \mathrm{w} / \mathrm{V})$ were combined and left stirring for $72 \mathrm{~h}$. The reaction mixture was filtered and precipitate was washed with acetone, and then recrystallised from water/ethanol-acetone to yield a white solid (1.4 g, yield $64 \%)$. ${ }^{1} \mathrm{H}$ NMR $\left(\mathrm{D}_{2} \mathrm{O}\right) \delta: 1.40-1.75(\mathrm{~m}, 12 \mathrm{H}), 1.75$ $-2.20(\mathrm{~m}, 4 \mathrm{H}), 2.90-3.05(\mathrm{~m}, 4 \mathrm{H}), 3.20-3.40(\mathrm{~m}, 4 \mathrm{H})$, $3.50-3.75(\mathrm{~m}, 4 \mathrm{H}), 3.75-4.10(\mathrm{~m}, 16 \mathrm{H}), 7.05(\mathrm{~s}, 8 \mathrm{H})$; ${ }^{13} \mathrm{C}$ NMR $\left(\mathrm{D}_{2} \mathrm{O}\right) \delta: 22.2,28.0,30.0,54.7,57.8,65.4,122.7$, $128.9,131.5,150.4,170.7$.

Synthesis of $N, N^{\prime}$-dibenzyl-4,4'-azopyridinium bromide: 4,4'-Azopyridine ( $0.184 \mathrm{~g}, 1.0 \mathrm{mmol})$ and $1.5 \mathrm{~mL}$ of benzyl bromide was placed in a round-bottom flask and stirred at $80{ }^{\circ} \mathrm{C}$ for $20 \mathrm{~h}^{\left[{ }^{[23]}\right.}$ The resulting solid was allowed to cool to room temperature and then washed with diethyl ether, then the yield solid was dried under vacuum. (0.81 g, yield 84\%). ${ }^{1} \mathrm{H}$ NMR (400 MHz, $\left.\mathrm{D}_{2} \mathrm{O}\right) \delta: 9.05$ (d, $J=6.5 \mathrm{~Hz}$, $4 \mathrm{H}), 8.42(\mathrm{~d}, J=6.6 \mathrm{~Hz}, 2 \mathrm{H}), 5.82(\mathrm{~s}, 4 \mathrm{H}), 7.42(\mathrm{~s}, 10 \mathrm{H})$. ESI-MS $(\mathrm{m} / \mathrm{z})$ : 263.1. Anal. calcd for $\mathrm{C}_{24} \mathrm{H}_{22} \mathrm{Br}_{2} \mathrm{~N}_{4}: \mathrm{C}$ 54.77, H 4.21, N 10.65; found C 54.75, H 4.20, N 10.66.

Synthesis of viologen bromides: The viologen bromides were synthesized according to the reported lecture. 4,4'-Bipyridinium (624 mg, $4.0 \mathrm{mmol})$ and alkylogen $(80.0$ $\mathrm{mmol}$ ) in $25 \mathrm{~mL}$ of $\mathrm{CH}_{3} \mathrm{CN}$ were stirred at $75{ }^{\circ} \mathrm{C}$ for $24 \mathrm{~h}$. After cooling the reaction mixture, precipitates were filtered and washed with $\mathrm{CH}_{3} \mathrm{CN}$, then the yield solid were dried under vacuum.

$\mathrm{EV}^{2+} \cdot 2 \mathrm{Br}^{-}:{ }^{1} \mathrm{H}$ NMR $\left(400 \mathrm{MHz}, \mathrm{D}_{2} \mathrm{O}\right) \delta: 9.03(\mathrm{~d}, J=6.0$ $\mathrm{Hz}, 4 \mathrm{H}), 8.44(\mathrm{~d}, J=6.6 \mathrm{~Hz}, 4 \mathrm{H}), 4.70-4.59(\mathrm{~m}, 8 \mathrm{H})$, $1.59(\mathrm{t}, J=7.2 \mathrm{~Hz}, 6 \mathrm{H})$; ESI-MS $(\mathrm{m} / \mathrm{z}): 176.3$. Anal. calcd for $\mathrm{C}_{14} \mathrm{H}_{18} \mathrm{Br}_{2} \mathrm{~N}_{2}$ : C 44.95, $\mathrm{H} 4.85, \mathrm{~N} 7.49$; found $\mathrm{C} 44.93$, $\mathrm{H} 4.84, \mathrm{~N} 7.46$.

$\mathrm{HV}^{2+} \cdot 2 \mathrm{Br}^{-}:{ }^{1} \mathrm{H}$ NMR $\left(400 \mathrm{MHz}, \mathrm{D}_{2} \mathrm{O}\right) \delta: 9.00(\mathrm{~d}, J=$ $6.7 \mathrm{~Hz}, 4 \mathrm{H}), 8.42(\mathrm{~d}, J=6.4 \mathrm{~Hz}, 4 \mathrm{H}), 4.61(\mathrm{t}, J=7.3 \mathrm{~Hz}$, $4 \mathrm{H}), 1.95(\mathrm{dd}, J=14.4,7.2 \mathrm{~Hz}, 4 \mathrm{H}), 1.21$ (ddd, $J=20.2$, 11.0, $5.3 \mathrm{~Hz}, 12 \mathrm{H}), 0.74$ (t, $J=7.1 \mathrm{~Hz}, 6 \mathrm{H})$; ESI-MS $(\mathrm{m} / \mathrm{z})$ : 273.2. Anal. calcd. for $\mathrm{C}_{22} \mathrm{H}_{34} \mathrm{Br}_{2} \mathrm{~N}_{2}$ : C 54.33, $\mathrm{H}$ 7.05, N 5.76; found C 54.32, H 7.06, N 5.78.

$\mathrm{BzV}^{2+} \cdot 2 \mathrm{Br}^{-}:{ }^{1} \mathrm{H}$ NMR $\left(400 \mathrm{MHz}, \mathrm{D}_{2} \mathrm{O}\right) \delta: 9.04(\mathrm{~d}, J=$ $6.8 \mathrm{~Hz}, 4 \mathrm{H}), 8.41(\mathrm{~d}, J=6.6 \mathrm{~Hz}, 4 \mathrm{H}), 7.41(\mathrm{~s}, 10 \mathrm{H}), 5.81$ (s, 4H); ESI-MS (m/z): 299.2. Anal. calcd for $\mathrm{C}_{24} \mathrm{H}_{22} \mathrm{Br}_{2} \mathrm{~N}_{2}$ : C 57.85, H 4.45, N 5.62; found C 57.83, H 4.46, N 5.60.

Synthesis of methyl viologen salts: The $\mathrm{MV}^{2+} \cdot 2 \mathrm{I}^{-}$was synthesized according to the reported procedure, then $\mathrm{MV}^{2+} \cdot 2 \mathrm{I}^{-}$was dissolved in water and $\mathrm{NaClO}_{4}$ was added to this solution. Precipitate was collected by centrifugation and washed with water. The precipitate was dissolved in $\mathrm{CH}_{3} \mathrm{CN}$ and $\mathrm{Et}_{4} \mathrm{NX}\left(\mathrm{X}=\mathrm{Cl}, \mathrm{Br}, \mathrm{NO}_{3}\right)$ was added to this solution. The precipitate was collected by centrifugation, washed with $\mathrm{CH}_{3} \mathrm{CN}$ and then dried under vacuum.

$\mathrm{MV}^{2+} \cdot 2 \mathrm{Br}^{-}:{ }^{1} \mathrm{H}$ NMR $\left(400 \mathrm{MHz}, \mathrm{D}_{2} \mathrm{O}\right) \delta: 8.93(\mathrm{~d}, J=$ $6.3 \mathrm{~Hz}, 4 \mathrm{H}), 8.42$ (d, $J=5.9 \mathrm{~Hz}, 4 \mathrm{H}), 4.39$ (s, 6H); ESI-MS $(\mathrm{m} / \mathrm{z})$ : 176.3. Anal. calcd for $\mathrm{C}_{12} \mathrm{H}_{14} \mathrm{Br}_{2} \mathrm{~N}_{2}$ : C 41.65, H 4.08, N 8.09; found C 41.34, H 3.78, N 8.04.
$\mathrm{MV}^{2+} \cdot 2 \mathrm{Cl}^{-}:{ }^{1} \mathrm{H}$ NMR $\left(400 \mathrm{MHz}, \mathrm{D}_{2} \mathrm{O}\right) \delta: 8.94(\mathrm{~d}, J=$ $6.2 \mathrm{~Hz}, 4 \mathrm{H}), 8.41(\mathrm{~d}, J=6.1 \mathrm{~Hz}, 4 \mathrm{H}), 4.38$ (s, 6H); ESI-MS $(m / z)$ : 176.3. Anal. calcd for $\mathrm{C}_{12} \mathrm{H}_{14} \mathrm{Cl}_{2} \mathrm{~N}_{2}$ : C 41.65, $\mathrm{H} 4.08$, $\mathrm{N}$ 8.09; found C 41.63, H 4.06, N 8.10.

$\mathrm{MV}^{2+} \cdot 2 \mathrm{NO}_{3}{ }^{-}:{ }^{1} \mathrm{H}$ NMR $\left(400 \mathrm{MHz}, \mathrm{D}_{2} \mathrm{O}\right) \delta: 8.92(\mathrm{~d}, J=$ $6.4 \mathrm{~Hz}, 4 \mathrm{H}), 8.43(\mathrm{~d}, J=5.9 \mathrm{~Hz}, 4 \mathrm{H}), 4.41(\mathrm{~s}, 6 \mathrm{H})$; ESI-MS $(m / z)$ : 176.3. Anal. calcd for $\mathrm{C}_{12} \mathrm{H}_{14} \mathrm{~N}_{4} \mathrm{O}_{6}$ : C 46.45, $\mathrm{H} 4.55$, $\mathrm{N} 18.06$; found C 46.4, H 4.56, N 18.04 .

\subsection{Preparation of hydrogels}

TPC and viologen salts were dissolved in deionized water. The solution was acidized to $\mathrm{pH} 3.0$ by a trace of conc. $\mathrm{HCl}$. Sealed and then immersed into a constanttemperature water bath at $70{ }^{\circ} \mathrm{C}$ for $20 \mathrm{~min}$ to afford a clear homogeneous solution. When the solution was cooled to room temperature, stable hydrogel was obtained.

\section{3 $T_{\text {gel }}$ Measurements}

$T_{\text {gel }}$ was determined by a "dropping-ball method", ${ }^{24]}$ a small ball (about $100 \mathrm{mg}$ ) was placed on top of the hydrogel in a test tube (inner diameter $1.0 \mathrm{~cm}$ ), which was slowly heated in a water bath with the increasing rate of 1 ${ }^{\circ} \mathrm{C} / \mathrm{min}$. The $T_{\text {gel }}$ was defined as the average value that the ball begins to fall and falls to the bottom of the test tube. All experiments were repeated three times.

\subsection{Powder X-ray diffraction analysis}

XRD tests for the crystal of TPC and the TPC/ $\mathrm{HV}^{2+}$. $2 \mathrm{Br}^{-}$xerogel were conducted on a Rigaku D/max 2500 diffractometer with $\mathrm{Cu} \mathrm{Ka}$ radiation $(40 \mathrm{kV}, 100 \mathrm{~mA})$. The samples were measured in the $2 \theta$ range from $3^{\circ}$ to $80^{\circ}$ at a scanning rate of $4\left(^{\circ}\right) / \mathrm{min}$.

\subsection{AFM Studies}

AFM was used to obtain the nanostructures of LMWHs. A thin film of the wet gel was placed on a freshly cleaved mica substrate and imaged in tapping mode on a multimode Veeco Nano IIIa atomic force microscope (Camarillo, USA). All of the measurements were performed in ambient air, and height images were recorded with $512 \times$ 512 pixel resolution.

\subsection{SEM Studies}

Morphologies of xerogels were investigated using SEM. For SEM study, gel materials were frozen in liquid $\mathrm{N}_{2}$ and then lyophilized. The micrographs were taken in HITACHI S-3500N SEM.

\subsection{Electrochemical experiments}

The cyclic voltammetric measurements were carried out on a BAS Epsilon electrochemical analyzer with $\mathrm{C} 3$ cell stand. The samples were prepared in $20 \mathrm{mmol} / \mathrm{L} \mathrm{PB}$ aqueous solutions at $25{ }^{\circ} \mathrm{C}$, and deoxygenated by purging with dry nitrogen before each experiment. The glassy carbon working electrode was polished with $0.05 \mu \mathrm{m}$ BAS alumina suspension on a brown Texmet polishing pad, sonicated in distilled water for a few minutes to remove any residual alumina particles, and then rinsed with ethanol before use. A platinum wire was used as the counter electrode. The measured potentials were recorded with respect to an $\mathrm{Ag} / \mathrm{AgCl}$ (immersed in a solution containing $3 \mathrm{~mol} / \mathrm{L}$ sodium chloride) reference electrode. The concentrations of TPC and $\mathrm{MV}^{2+} \cdot 2 \mathrm{Br}^{-}$were both $2.5 \mathrm{mmol} / \mathrm{L}$, respectively. The scan rate was $100 \mathrm{mV} / \mathrm{s}$. The electrochemical 
reduction of $\mathrm{TPC} / \mathrm{MV}^{2+} \cdot 2 \mathrm{Br}^{-}$hydrogel was performed as follows: $5.0 \mathrm{mmol} / \mathrm{L} \mathrm{TPC}$ and $\mathrm{MV}^{2+} \cdot 2 \mathrm{Br}^{-}$were allowed to gelate in a $1 \mathrm{~cm}$ cell, containing $5.0 \mathrm{mmol} / \mathrm{L} \mathrm{NaCl}$ as the supporting electrolyte. A thin platinum plate as working electrode, a platinum wire as counter electrode and an $\mathrm{Ag} / \mathrm{AgCl}$ electrode as reference electrode were carefully inserted into the hydrogel, and then the reduction potential was applied for the hydrogel for $20 \mathrm{~min}$.

\subsection{Thermoreversible experiments}

The fluorescence intensity of ANS was followed while the temperature was raised gradually from $25{ }^{\circ} \mathrm{C}$ to 70 ${ }^{\circ} \mathrm{C}$; in the next step, the fluorescence intensity of the hot sample was recorded while its temperature was decreased gradually from $70{ }^{\circ} \mathrm{C}$ to $25{ }^{\circ} \mathrm{C}$. Fluorescence spectra were measured in a conventional rectangular quartz cell $(10 \mathrm{~mm}$ $\times 10 \mathrm{~mm} \times 45 \mathrm{~mm})$ on a VARIAN CARY Eclipse spectrometer at an excitation wavelength $360 \mathrm{~nm}$.

\section{References}

[1] Steed, J. W. Chem. Commun. 2011, 47, 1379.

[2] Estroff, L. A.; Hamilton, A. D. Chem. Rev. 2004, 103, 1201.

[3] (a) Murata, K.; Aoki, M.; Suzuki, T.; Harada, T.; Kawabata, H.; Komori, T.; Ohseto, F.; Ueda, K.; Shinkai, S. J. Am. Chem. Soc. 1994, 116, 6664; (b) Yagai, S.; Nakajima, T.; Kishikawa, K.; Kohmoto, S.; Karatsu, T.; Kitamura, A. J. Am. Chem. Soc. 2005, 127, 11134; (c) Suzuki, T.; Shinkai, S.; Sada, K. Adv. Mater. 2006, 18, 1043; (d) Eastoe, J.; Sánchez-Dominguez, M.; Wyatt, P.; Heenan, R. K. Chem. Commun. 2004, 2608; (e) Ji, Y.; Kuang, G. C.; Jia, X. R.; Chen, E.-Q.; Wang, B.-B.; Li, W.-S.; Wei, Y.; Lei, J. Chem. Commun. 2007, 4233; (h) Kim, J. H.; Seo, M.; Kim, Y. J.; Kim, S. Y. Langmuir 2009, 25, 1761 .

[4] (a) Geiger, C.; Stanescu, M.; Chen, L.-H.; Whitten, D. G. Langmuir 1999, 15, 2241; (b) Wang, R.; Geiger, C.; Chen, L.-H.; Swanson, B.; Whitten, D. G. J. Am. Chem. Soc. 2000, 122, 2399; (c) Dong, S.; Zheng, B.; Xu, D.; Yan, X.; Zhang, M.; Huang, F. Adv. Mater. 2012, 24; (d) Yan, X.; Xu, D.; Chi, X.; Chen, J.; Dong, S.; Ding, X.; Yu, Y.; Huang, F. Adv. Mater. 2012, 24, 362; (e) Dong, S.; Luo, Y.; Yan, X.; Zheng, B.; Ding, X.; Yu, Y.; Ma, Z.; Zhao, Q.; Huang, F. Angew. Chem., Int. Ed. 2011, 50, 1905.

[5] (a) Kawano, S. I.; Fujita, N.; Shinkai, S. J. Am. Chem. Soc. 2004, 126, 8592; (b) Kawano, S.; Fujita, N.; Shinkai, S. Chem. Eur. J.
2005, 11, 4735; (c) Zhao, Y.-L.; Aprahamian, I.; Trabolsi, A.; Erina, N.; Stoddart, J. F. J. Am. Chem. Soc. 2008, 130, 6348; (d) Liu, J.; Yan, J.-L.; Yuan, X.-W.; Liu, K.-Q.; Peng, J.-X.; Fang, Y. J. Colloid Interface Sci. 2008, 318, 397.

[6] (a) Akutagawa, T.; Kakiuchi, K.; Hasegawa, T.; Noro, S.; Nakamura, T.; Hasegawa, H.; Mashiko, S.; Becher, J. Angew. Chem., Int. Ed. 2005, 44, 7283; (b) Kitahara, T.; Shirakawa, M.; Kawano, S.; Beginn, U.; Fujita, N.; Shinkai, S. J. Am. Chem. Soc. 2005, 127, 14980; (c) Puigmartı'-Luis J.; Laukhin, V.; del Pino A. P.; VidalGancedo, J.; Rovira, C.; Laukhina, E.; Amabilino, D. B. Angew. Chem., Int. Ed. 2007, 46, 238; (d) Puigmartí-Luis, J.; Del Pino, A P.; Laukhina, E.; Esquena, J.; Laukhin, V.; Rovira, C.; Vidal-Gancedo, J.; Kanaras, A. G.; Nichols, R. J.; Brust, M.; Amabilino, D. B. Angew. Chem., Int. Ed. 2008, 47, 1861.

[7] Wang, C.; Chen, Q.; Sun, F.; Zhang, D. Q.; Zhang, G. X.; Huang, Y.-Y.; Zhao, R.; Zhu, D.-B. J. Am. Chem. Soc. 2010, 132, 3092.

[8] Fang, L.; Basu, S.; Sue, C. H.; Fahrenbach, A. C.; Stoddart, J. F. J. Am. Chem. Soc. 2011, 133, 396

[9] de Loos, M.; Feringa, B. L.; van Esch, J. H. Eur. J. Org. Chem. 2005, 17, 3615 .

[10] Steed, J. W.; Foster, J. A. Angew. Chem., Int. Ed. 2010, 49, 6718.

[11] Taira, T.; Suzaki, Y.; Osakada, K. Chem. Commun. 2009, 7027.

[12] Hwang, I.; Jeon, W. S.; Kim, H. J.; Kim, D.; Kim, H.; Selvapalam, N.; Fujita, N.; Shinkai, S.; Kim, K. Angew. Chem., Int. Ed. 2007, 46, 210 .

[13] Becker, T.; Goh, C. Y.; Jones, F.; McIldowie, M. J.; Mocerino, M.; Ogden, M. I. Chem. Commun. 2008, 3900.

[14] Goh, C. Y.; Becker, T.; Brown, D. H.; Skelton, B. W.; Jones, F.; Mocerino, M.; Ogden, M. I. Chem. Commun. 2011, 47, 6057.

[15] Zhang, J.; Guo, D.-S.; Wang, L.-H.; Wang, Z.; Liu, Y. Soft Matter 2011, 7, 1756.

[16] Bird, C. L.; Kuhn, A. T. Chem. Soc. Rev. 1981, 10, 49.

[17] Balzani, V.; Credi, A.; Raymo, F. M.; Stoddart, J. F. Angew. Chem., Int. Ed. 2000, 39, 3348.

[18] Monk, P. M. S. The Viologens: Physicochemical Properties, Synthesis and Applications of the Salts of 4,4'-Bipyridine, John Wiley \& Sons, Chichester, England, 1998.

[19] Wang, K.; Guo, D.-S.; Wang, X.; Liu, Y. ACS Nano 2011, 5, 2880.

[20] Tomatsu, I.; Hashidzume, A.; Harada, A. Macromol. Rapid Commun. 2006, 27, 238.

[21] Iyere, P. A. Chem. Mater. 1995, 7, 2224.

[22] (a) Dutta, S.; Shome, A.; Debnath, S.; Das, P. K. Soft Matter 2009, 5, 1607; (b) Burt, M. C.; Dave, B. C. J. Am. Chem. Soc. 2006, 128, 11750 .

[23] Iranpoor, N.; Firouzabadi, H.; Khalili, D.; Motevalli, S. J. Org. Chem. 2008, 73, 4882.

[24] Terech, P.; Rossat, C.; Volino, F. J. Colloid Interface Sci. 2000, 227, 363. 